\title{
Implications of Nursing Clinical Practice to The Student's Spiritual Health
}

\author{
Asthadi Mahendra Bhandesa ${ }^{*}$ I G A Puja Astuti, Ni Putu Kartiningsih \\ Institute of Health Sciences Bali
}

\begin{abstract}
This study aimed to clarify the implications of Nursing Clinical Practice (PLKK) to the spiritual health of STIKES Bali students. This study employed purposive sampling method to determine the number of respondents. To conduct this study, the fourth grade of nursing students were recruited as the sample with total number 136 respondents. A questionnaire about spirituality from World Health Organization (WHO) was used in this study as the instrument. In addition, the data were analysed by using quantitative descriptive technique. The result showed that $50.0 \%$ of students had a very good spiritual health, $42.6 \%$ had good spiritual health, $6.6 \%$ had moderate spiritual health, and $0.7 \%$ had poor spiritual health. It can be interpreted that spiritual health of nursing students of STIKES Bali is good after conducting Nursing Clinical Practice. Thus, this study can be concluded that Nursing Clinical Practice has implication to the ability of students to love themselves and others meaningfully as the evidence of students' spiritual health.
\end{abstract}

Keywords: Spiritual Health, Nursing Clinical Practices, Nursing Students.

\section{INTRODUCTION}

Spiritual health in health education is an integrated part to form professional health workers in accordance with international standards. Nurses have an important role in improving the quality of public health. Nurses are required to appear professionally while providing nursing care and able to establish cooperation with various parties to provide services provided comprehensive and can meet basic needs, including the needs of bio, psycho, socio, and spiritual clients [14].

Nursing services provided to the public must meet international quality standards, which can be ensure the safety and the comfort of clients and their families. Nurses are required to perform professionally when providing nursing care and able to establish cooperation with various parties to provide services comprehensively and able meet basic needs, including the needs of bio, psycho, socio and spiritual clients [15].

The health is justly as a pyramid which could divide into three parts: physical, mental and spiritual. A complete health comprised the satisfactory state of physiological, psychological and spiritual needs. The current students enjoy the high quality of material life with the noble clothes and the delicacy, but their spiritual life are vanity [3].

* Corresponding author: Bhandesa_asthadi@stikes-bali.ac.id 
As an effort to achieve academic ability, in accordance with the expected competence, the students of STIKES Bali are given the opportunity to Nursing Clinical Practice (PLKK). PLKK is a process by which students practice to improve nursing skills. Through the implementation of the nursing process, students are expected to be able to conduct assessment, planning, implementation and evaluate and do documentation in meeting with bio-psycho-social-spiritual health problems.

Empirically the students make contact with the patient so that in both personality and skills able to develop. As the real cases in practice areas that concern with various aspects of nursing will have implications for students, one of them is in the aspect of spiritual health, whereas students as a prospective nurse as a professional health worker has greater opportunity to provide comprehensive nursing care by helping clients meet their basic holistic needs. Students also have the ability to view clients as bio-psycho-sociocultural and spiritual beings, so indirectly the interaction also affects the personality and skills of students, one of them is in the aspect of spiritual health.

From the philosophical, theoretical, and empirical backgrounds of this study, this research becomes very important. This is because PLKK is one of the processes in nursing education so that students are able to apply knowledge and skills in the form of nursing care as well as one of the factors that can build the spiritual health of the students.

\section{METHODS}

This study employed descriptive quantitative design. The sample were determined through purposive sampling technique. The sample in this study were the fourth grade of nursing students of bachelor program at Institute of Health Sciences Bali who have done PLKK IV with 136 respondents. The data were collected by using the instruments of spiritual health questionnaires from WHO. Data were then analysed by using quantitative descriptive technique. The category of spiritual health of students after PLKK IV was grouped into four categories, those categories were very good, good, enough and less

\section{RESULTS AND DISCUSSION}

Nursing Clinical Service and its implication for student's spiritual health was carried out in STIKES Bali and conducted on the students of bachelor of nursing program academic year of 2016/ 2017 who had implemented PLKK IV. From the total population of 206 students, the sample of the study was taken using the sampling formula to obtain a sample of 136 students. Implications of nursing clinical service on the spiritual health of STIKES Bali students were presented with 32 statements.

Table 1. Implications of nursing clinical practice on spiritual health Student Grade IV in Bachelor of Nursing Program

\begin{tabular}{|c|l|c|c|c|c|c|c|c|c|c|c|}
\hline \multirow{2}{*}{ No. } & \multicolumn{1}{|c|}{ Statements } & TA & S & B & SB & SBS & $\begin{array}{r}\text { T } \\
\text { A }\end{array}$ & S & B & SB & SBS \\
\cline { 3 - 10 } & & & 1 & 16 & 64 & 55 & & 0,7 & 11,8 & 47,1 & 40,4 \\
& $\begin{array}{l}\text { How much does your } \\
\text { spiritual connection help to overcome your } \\
\text { hardest moments? }\end{array}$ & $\begin{array}{l}\text { How much does the } \\
\text { influence of your spiritual } \\
\text { relationship help you to } \\
\text { tolerate stress? }\end{array}$ & 3 & 31 & 66 & 38 & & 2,2 & 22,8 & 47,1 & 27,9 \\
\hline
\end{tabular}




\begin{tabular}{|c|c|c|c|c|c|c|c|c|c|c|c|}
\hline 3 & $\begin{array}{l}\text { How much does the } \\
\text { influence of your spiritual } \\
\text { relationships help you to } \\
\text { understand about the } \\
\text { circumstances of those } \\
\text { around you? }\end{array}$ & 2 & 3 & 47 & 59 & 25 & 1,5 & 2,2 & 34,6 & 43,4 & 18,4 \\
\hline 4 & $\begin{array}{l}\text { How much does your } \\
\text { spiritual connection give } \\
\text { you comfort/ tranquility } \\
\text { within you? }\end{array}$ & & & 27 & 55 & 54 & & & 19,9 & 40,4 & 39,7 \\
\hline 5 & $\begin{array}{l}\text { How much have you } \\
\text { discovered the meaning of } \\
\text { life in your life? }\end{array}$ & & 30 & 57 & 34 & 15 & & 22,1 & 41,9 & 25,0 & 11,0 \\
\hline 6 & $\begin{array}{l}\text { How much does someone } \\
\text { else give meaning to in your } \\
\text { life? }\end{array}$ & & 3 & 51 & 34 & 48 & & 2,2 & 37,5 & 25,0 & 35,3 \\
\hline 7 & $\begin{array}{l}\text { How much do you feel the } \\
\text { life you live on has a } \\
\text { specific purpose? }\end{array}$ & & 9 & 42 & 53 & 32 & & 6,6 & 30,9 & 39,0 & 23,5 \\
\hline 8 & $\begin{array}{l}\text { How much do you have } \\
\text { reason to survive in this life? }\end{array}$ & 1 & 2 & 23 & 49 & 61 & 0,7 & 1,5 & 16,9 & 36,0 & 44,9 \\
\hline 9 & $\begin{array}{l}\text { How much do you feel the } \\
\text { spiritual power within you? }\end{array}$ & & 5 & 38 & 59 & 34 & & 3,7 & 27,9 & 43,4 & 25,0 \\
\hline 10 & $\begin{array}{l}\text { How much do you feel in } \\
\text { getting spiritual power in } \\
\text { your hardest moments? }\end{array}$ & & 3 & 32 & 55 & 45 & & 2,2 & 23,7 & 40,7 & 33,3 \\
\hline 11 & $\begin{array}{l}\text { How much trust do you have } \\
\text { to contribute to the } \\
\text { welfareness of your life? }\end{array}$ & & 5 & 31 & 65 & 35 & & 3,7 & 22,8 & 47,8 & 25,7 \\
\hline 12 & $\begin{array}{l}\text { How much confidence do } \\
\text { you have in your daily life? }\end{array}$ & & 7 & 28 & 68 & 33 & & 5,1 & 20,6 & 50,0 & 24,3 \\
\hline 13 & $\begin{array}{l}\text { How much trust do you have } \\
\text { to give strength in everyday } \\
\text { life? }\end{array}$ & & 6 & 28 & 68 & 34 & & 4,4 & 20,6 & 50,0 & 25,0 \\
\hline 14 & $\begin{array}{l}\text { How much do you feel your } \\
\text { spirituality in every beauty } \\
\text { within you? }\end{array}$ & & 6 & 35 & 70 & 25 & & 4,4 & 25,7 & 51,5 & 18,4 \\
\hline 15 & $\begin{array}{l}\text { How much inspiration do } \\
\text { you feel able to help you in } \\
\text { your life? }\end{array}$ & & 8 & 36 & 55 & 37 & & 5,9 & 26,5 & 40,4 & 27,2 \\
\hline 16 & $\begin{array}{l}\text { How much you be grateful } \\
\text { for everything you can enjoy } \\
\text { from nature? }\end{array}$ & & 5 & 22 & 34 & 75 & & 3,7 & 16,2 & 25,0 & 55,1 \\
\hline 17 & $\begin{array}{l}\text { How is the life expectancy } \\
\text { that you feel? }\end{array}$ & 2 & 1 & 29 & 52 & 52 & 1,5 & 0,7 & 21,3 & 38,2 & 38,2 \\
\hline 18 & $\begin{array}{l}\text { How much hope do you } \\
\text { have about the life you are } \\
\text { living today? }\end{array}$ & & & 20 & 64 & 52 & & & 14,7 & 47,1 & 38,2 \\
\hline 19 & $\begin{array}{l}\text { How much do you express } \\
\text { your admiration for } \\
\text { something around you? } \\
\text { (i.e. nature, art, music) }\end{array}$ & & 2 & 18 & 55 & 61 & & 1,5 & 13,2 & 40,4 & 44,9 \\
\hline 20 & $\begin{array}{l}\text { How much do you feel } \\
\text { about connection between } \\
\text { mind, body and soul? }\end{array}$ & & 3 & 23 & 61 & 49 & & 2,2 & 16,9 & 44,9 & 36,0 \\
\hline 21 & $\begin{array}{l}\text { How much do you feel } \\
\text { about your way of life is in } \\
\text { line with what you feel and } \\
\text { think about? }\end{array}$ & & 10 & 40 & 66 & 20 & & 7,4 & 29,4 & 48,5 & 14,7 \\
\hline
\end{tabular}




\begin{tabular}{|c|c|c|c|c|c|c|c|c|c|c|c|}
\hline 22 & $\begin{array}{l}\text { How much trust do you have } \\
\text { to help you align what you } \\
\text { do, think and feel? }\end{array}$ & & 4 & 38 & 63 & 31 & & 2,9 & 27,9 & 46,3 & 22,8 \\
\hline 23 & $\begin{array}{l}\text { How much spiritual power } \\
\text { helps you to experience a } \\
\text { better life? }\end{array}$ & & & 19 & 71 & 46 & & & 14,0 & 52,2 & 33,8 \\
\hline 24 & $\begin{array}{l}\text { How much spiritual power } \\
\text { helps you to experience } \\
\text { happiness in this life? }\end{array}$ & & 2 & 16 & 75 & 43 & & 1,5 & 11,8 & 55,1 & 31,6 \\
\hline 25 & $\begin{array}{l}\text { How much do you feel the } \\
\text { peace in your heart? }\end{array}$ & & 5 & 30 & 67 & 34 & & 3,7 & 22,1 & 49,3 & 25,0 \\
\hline 26 & $\begin{array}{l}\text { How much do you have } \\
\text { peace in your heart? }\end{array}$ & & 6 & 30 & 65 & 35 & & 4,4 & 22,1 & 47,8 & 25,7 \\
\hline 27 & $\begin{array}{l}\text { How much can you feel for } \\
\text { peace in your heart if you } \\
\text { need it? }\end{array}$ & & 5 & 35 & 71 & 25 & & 3,7 & 25,7 & 52,2 & 18,4 \\
\hline 28 & $\begin{array}{l}\text { How much can you feel the } \\
\text { touch of harmony within } \\
\text { yourself? }\end{array}$ & & 7 & 34 & 57 & 38 & & 5,1 & 25,0 & 41,9 & 27,9 \\
\hline 29 & $\begin{array}{l}\text { How much optimistic are } \\
\text { you to develop the quality of } \\
\text { life you have today? }\end{array}$ & & 2 & 27 & 67 & 40 & & 1,5 & 19,9 & 49,3 & 29,4 \\
\hline 30 & $\begin{array}{l}\text { How capable can you } \\
\text { maintain your optimism in } \\
\text { the uncertain circumstances } \\
\text { you experience? }\end{array}$ & 2 & 5 & 31 & 74 & 24 & 1,5 & 3,7 & 22,8 & 54,4 & 17,6 \\
\hline 31 & $\begin{array}{l}\text { How much trust do you have } \\
\text { to help you enjoy life? }\end{array}$ & & & 26 & 64 & 46 & & & 19,1 & 47,1 & 33,8 \\
\hline 32 & $\begin{array}{l}\text { How satisfied are you, when } \\
\text { you find a balance between } \\
\text { your mind, body and soul? }\end{array}$ & & 1 & 28 & 68 & 39 & & 0,7 & 20,6 & 50,0 & 28,7 \\
\hline
\end{tabular}

Information:

TA : None

$\mathrm{S} \quad$ : A little

$\mathrm{B} \quad$ : Big

SB : Very Big

SBS : Very Great

The category of spiritual health of the students after the PLKK is categorized into four, that is very good, good, enough and less. The categories are shown in Table 2.

Table 2. Category of spiritual health of fourth grade students of bachelor of nursing after PLKK IV

\begin{tabular}{|c|c|c|c|}
\hline No. & Category & Frequency(s) & Percentage (\%) \\
\hline 1 & Very Good & 68 & 50,0 \\
\hline 2 & Good & 58 & 42,6 \\
\hline 3 & Enough & 9 & 6,6 \\
\hline 4 & Less & 1 & 0,7 \\
\hline Total & & $\mathbf{1 3 6}$ & $\mathbf{1 0 0}$ \\
\hline
\end{tabular}

Based on the results of the research above, it could be shown that $50.0 \%$ of nursing students of grade IV had excellent spiritual health and $42,6 \%$ had good spiritual health after PLKK IV. Kozier et al [3] states that because spirituality was a reflection of internal experience (inner experience) that was expressed individually, then spirituality presents from many aspects in human beings such as religion, belief, hope, transcendence and forgiveness. Spirituality is one that influenced by culture, development, life experiences of 
trust and value of life. Spirituality could bring love, trust, and hope, see the meaning of life and nurture relationships [12]. The ability to love others and self was meaningfully the evidence of spiritual health. Establishing a relationship with the great, life, or value was one way of developing spirituality. Health of healthy spirituality was something that gave peace and acceptance about self and it was often based on a lasting relationship with the Supreme God. Spiritual health was achieved when one found a balance between the value of life, the purpose of life, the belief system, and one's relationship with oneself or others.

\section{CONCLUSION}

Based on the discussion above, it could be concluded that there are $50.0 \%$ of students have excellent spiritual health, $42.6 \%$ have good spiritual health, $6.6 \%$ have adequate spiritual health, and $0.7 \%$ have inadequate spiritual health after the implementation of PLKK IV. This research is expected to be the basis for Bali STIKES to evaluate the implementation and improve the implementation process of Nursing Clinical Practice. PLKK could be received well and receive good perception among students therefore it could be improved in accordance with the development of the world of health and education. In addition, research on Nursing Clinical Practice in next research should be developed with input and review from other variables so that the improvements in the implementation of PLKK could be improved.

\section{ACKNOWLEDGEMENT}

I would like to express my deepest gratitude to I Gede Putu Darma Suyasa, S.Kp.,M.Ng.,Ph.D. as the director of Institute of Health and Sciences (STIKES) Bali for the support in conducting this study. In addition, I would like to thank to the Centre for Research and Community Service (P3M) STIKES Bali; as well as gratitude to the family, and colleagues who have provided input in the preparation of this manuscript.

\section{References}

1. Alyssa N. Bryant. (2008). The Spiritual Struggles of College Students: Illuminating a Critical Developmental Phenomenon. Vol. 4. Issue 4. Spirituality in Higher Education Newsletter.

2. Anand, Varun; Jones, June; Gill, Paramjit (2015). The Relationship Between Spirituality, Health and Life Satisfaction of Undergraduate Students in the UK: An Online Questionnaire Study. 54:160-172. https://doi.org/10.1007/s10943-013-9792-0.

3. Chin-Moucheng,Yao-Yuanliu,\& Rong-Lainho. (2006). The Impact of Internet Technology on Spiritual Health of College Students. April 16-18. pp33-38. Proceedings of the 5th WSEAS International Conference on Applied Computer Science, Hangzhou, China.

4. Donia Baldacchino. (2015). Spiritual Care Education of Health Care Professionals. 6, 594-613. http://doi.org/10.3390/rel6020594

5. Hamid, A.Y.S. 2009. Bunga Rampai Asuhan Keperawatan Kesehatan Jiwa. Jakarta: EGC.

6. Jalaludin Rakhmat 2011. Psikologi Komunikasi. Bandung: PT.Remaja Rosdakarya.

7. Kozier, B et al. 1997. Fundamental of Nursing Practice in Canada (1th Canadian ed). New Jersey: Prentice Hall Inc. 
8. Kozier, B et al. 2004. Fundamental of Nursing Consepts, Process, and Practice (7th Canadian ed). New Jersey: Prentice Hall Inc.

9. Lee-Ann O'brien, Simon Denny, Terryann Clark, Theresa Fleming, Tasileta Teevale \& Elizabeth Robinson (2013). The impact of religion and spirituality on the risk behaviours of young people in Aotearoa, New Zealand. Vol. 32 Number 4. Youth Studies Australia.

10. Maryam Azizi, Abolfath Azizi, Ahmad Abedi, Mohamad Baqher Kajbaf, Reza Ali Fallahzadeh. (2016) The Effect of Spiritual Therapy on Hope of Life in Female Students Who Referred to Isfahan University Counseling Center. 7. 126-131. http://www.scirp.org/journal/psych http://dx.doi.org/10.4236/psych.2016.71015.

11. Norwati Mansora, Nur Syahidah Khalidb. (2012). Spiritual well-being of INSTED, IIUM Students' and Its Relationship with College Adjustment. Vol. 69. 1314 - 1323. Procedia - Social and Behavioural Sciences. Elsevier.

12. Perry\&Potter. 2005. Buku Ajar Fundamental Keperawatan Konsep, Proses, dan Praktik. Ed.4.Vol. 1.Jakarta : EGC.

13. Park, J. J., \& Millora, M. (2010). Psychological well-being for White, Black, Latino/a, and Asian American students: Considering spirituality and religion. Journal of Student Affairs Research and Practice, 47(4), 1-18. https://doi.org/10.2202/1949-6605.6143 Available at http://journals.naspa.org/jsarp/vol47/iss4/art3/. Innovations in Research and Scholarship Feature.

14. Ristekdikti dan PPNI. 2015. Kurikulum Pendidikan Ners Indonesia. Jakarta: AIPNI.

15. Ristekdikti dan PPNI. 2015. Kurikulum Inti Pendidikan Ners 2015. Jakarta: AIPNI.

16. Ya-Chu Hsiao, Hui-Ying Chiang, Hsiang-Chun Lee \& Su-Hui Chen. (2012). The Effects of a Spiritual Learning Program on Improving Spiritual Health and Clinical Practice Stress Among Nursing Students. VOL. 20, NO. 4. The Journal of Nursing Research. 